medRxiv preprint doi: https://doi.org/10.1101/2020.12.22.20248695; this version posted December 24, 2020. The copyright holder for this preprint (which was not certified by peer review) is the author/funder, who has granted medRxiv a license to display the preprint in It is made available under a CC-BY-NC 4.0 International license.

\title{
THE SEARCH FOR AN ASSOCIATION OF HLA ALLELES AND COVID-19 RELATED MORTALITY IN THE RUSSIAN POPULATION
}

\section{The list of authors}

\section{Valery Cheranev $^{1}$, Irina Bulusheva ${ }^{1}$, Valery Vechorko ${ }^{1}$, Dmitriy Korostin ${ }^{1}$, Denis Rebrikov ${ }^{1}$ \\ ${ }^{1}$ Center for Precision Genome Editing and Genetic Technologies for Biomedicine, Pirogov Medical University, 1 Ostrovityanova Street, 117997 Moscow, Russia}

\begin{abstract}
HLA genes play a pivotal role in an immune response via the presentation of pathogen peptides in a complex on the surface of cells of a host organism. Here, we studied the association of class I and class II genes with the severity of COVID-19 infection and HLA allele variants.

We performed high-resolution sequencing of class I and class II HLA genes using the sample population of 147 patients who died of COVID-19 and statistically compared our results with the frequencies of the HLA genotypes in a control population of 270 samples.

The obtained data demonstrated that 51:05 and 15:18 alleles from locus $\mathrm{B}^{*}$ are statistically significantly associated with COVID-19 severity, while $C^{*} 14: 02$ allele correlates with the probability of death from COVID-19 for patients without comorbidities.
\end{abstract}

\section{Introduction}

In 2020, the human population faced an epidemic that affected almost all countries to a certain degree. It was caused by a new virus from the Coronaviridae family SARSCoV-2 [1]. The first outbreak of the disease was registered in Wuhan (China) and the disease rapidly spread over the other countries. Currently, the number of registered cases exceeds 53 million, 1.3 million being lethal [2]. In January 2020, the World Health Organization (WHO) declared the outbreak to be a pandemic and termed the disease caused by the virus COVID-19.

One of the essential factors facilitating the rapid spread of COVID-19 is a difference in the severity of a disease and its manifestations widely ranging in individual patients $[3,4,5]$. The accumulated data on SARS-CoV-2 suggest some correlation between the disease outcome and sex, age, and concurrent diseases [6]. Disease severity can be also associated with individual genetic characteristics of a

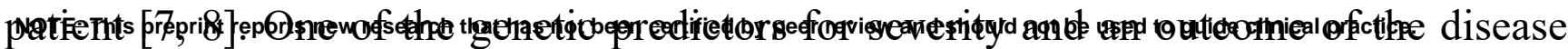
could be class I and II HLA genes encoding the proteins of the major histocompatibility 
medRxiv preprint doi: https://doi.org/10.1101/2020.12.22.20248695; this version posted December 24, 2020. The copyright holder for this

preprint (which was not certified by peer review) is the author/funder, who has granted medRxiv a license to display the preprint in

It is made available under a CC-BY-NC 4.0 International license .

2

complex (MHC). The main function of these molecules is presenting an antigen on the surface of the plasma membrane for their recognition by immune cells. Therefore, the alleles encoding the aminoacid sequence in MHC directly affect the susceptibility to certain diseases. Based on the data on the alleles of class I and II HLA genes and the protein composition of SARS-CoV-2, we analyzed the level of the affinity of MHC binding to all possible viral epitopes [9]. The lowest predicted level of the interaction with viral antigens belonged to the protein encoded by $B^{*} 46: 01$ allele while the highest level belonged to the $\mathrm{B}^{*} 15: 03$ allele. Thus, we proceeded with a retrospective analysis aimed to reveal any association between the identified alleles and disease severity [1015].

Previously, the correlation between HLA alleles and the disease in the test and control groups was performed using statistical analysis by the 2-level procedure of identification of significant alleles [16]. On the first stage, the distribution of all alleles in patients was compared to the distribution of the reference population in order to choose several candidate alleles. After that, candidate alleles were compared between two groups of patients using the Bonferroni method.

The correlation between HLA and the disease was studied at the background of concurrent diseases $[17,18,19]$.

In our work, we compared the frequencies of different alleles of class I (A, B, C) and class II (DRB1, DQB1) HLA genes between the groups of patients and healthy donors. The main goal of the work is to identify and validate the alleles significantly related to various COVID-19 outcomes.

\section{Background}

\section{Materials and methods}

\section{Ethics statement}

This study conformed to the principles of the Declaration of Helsinki. The appropriate institutional review board approval for this study was obtained from the Ethics Committee at Pirogov Medical University. All patients provided written informed consent for the collection of samples, subsequent analysis, and publication thereof.

\section{Biomaterial collection}

The biomaterial consisting of whole venous blood was collected in EDTA-coated tubes used as a preservative.

\section{gDNA isolation}

gDNA was isolated from $100 \mathrm{ul}$ of whole venous blood with Proba-Mch-Maks reagent kit using automated dosing station ДТстрим (DT stream) (DNA Technology, Russia). Quality check of the isolated DNA was performed using gel electrophoresis in agarose gel, the concentration was measured using Qubit 2 fluorimeter with Qubit dsDNA BR Assay kit (ThermoFisher Scientific, USA). 
medRxiv preprint doi: https://doi.org/10.1101/2020.12.22.20248695; this version posted December 24, 2020. The copyright holder for this preprint (which was not certified by peer review) is the author/funder, who has granted medRxiv a license to display the preprint in

It is made available under a CC-BY-NC 4.0 International license.

\section{HLA library preparation}

The preparation of amplicon libraries for HLA high-resolution genotyping was performed using HLA Expert kit (DNA Technology, Russia), following the manufacturer's protocol.

\section{Sequencing}

Sequencing was performed with Illumina MiSeq using MiSeq Reagent Kit v3 (600-cycle), according to the manufacturer's instructions.

\section{HLA high-resolution genotyping}

The analysis of fastq files was performed with HLA-Expert software v.2.0 (DNA Technology, Russia) according to the manufacturer's protocol.

\section{Statistical Analysis}

Statistical analysis was performed using Arlequin v.3.5.2.2 [16] and Pearson's goodness-of-fit test. We created several scripts allowing for estimating the diversity of each gene and differences in frequencies of the individual alleles in groups. We also created a script that cleared an input table containing patients' data from errors and transformed the names of HLA alleles, according to a unified syntax (https://github.com/genomecenter/HLA_article). We created a script that generated an input file containing patients' data for Arlequin.

\section{Results}

As a study population, we used a collection of venous blood samples and clinical data from 147 patients (group III) that had died in Moscow clinics from coronavirus disease COVID-19 during the pandemic in 2020. The positive test for COVID-19 was confirmed using qPCR kits in Moscow clinical diagnostic laboratories that collected the biomaterial. Clinical features of the group III is presented in Table 1. As the control sample population, we used 270 venous blood samples collected from the members of the National Registry of Bone Marrow Donors by the Pirogov Medical University at the beginning of 2020. All members of the control sample population were surveyed and stratified into two groups: those who hadn't suffered from COVID-19 during our study (245 samples, group 1) and those who had recovered from COVID-19.

Table 1. Clinical data in the cohort of deceased patients with COVID-19.

\begin{tabular}{|l|c|c|c|}
\hline & $\begin{array}{c}\text { Age 65 years and } \\
\text { below }\end{array}$ & Above 65 years old & $\begin{array}{c}\text { No full clinical } \\
\text { presentation }\end{array}$ \\
\hline The number of patients & 30 & 67 & 50 \\
\hline Age, median, Q25-Q75 & $58(52.5-62.75)$ & $81(74.5-86)$ & - \\
\hline Sex & 15 & 42 & - \\
\hline Female & \multicolumn{3}{|c|}{} \\
\hline
\end{tabular}




\begin{tabular}{|c|c|c|c|}
\hline \multicolumn{4}{|c|}{4} \\
\hline Male & 15 & 25 & - \\
\hline Comorbidities & 24 & 59 & - \\
\hline Acute respiratory infection & 1 & 0 & - \\
\hline $\begin{array}{l}\text { Pneumonia in the absence of respiratory } \\
\text { failure }\end{array}$ & 3 & 6 & - \\
\hline ARDS & 13 & 20 & - \\
\hline Sepsis, septic shock & 5 & 3 & - \\
\hline Thromboses, embolism & 10 & 17 & - \\
\hline Skin rashes & 0 & 0 & - \\
\hline DIC & 0 & 0 & - \\
\hline Multiple organ failure & 12 & 13 & - \\
\hline $\begin{array}{l}\text { Chronic inflammatory infectious } \\
\text { diseases }\end{array}$ & 2 & 15 & - \\
\hline $\begin{array}{l}\text { Autoimmune diseases including type } 1 \\
\text { diabetes mellitus }\end{array}$ & 0 & 1 & - \\
\hline $\begin{array}{l}\text { Metabolic diseases including type } 2 \\
\text { diabetes mellitus }\end{array}$ & 10 & 11 & - \\
\hline Cardiovascular diseases & 17 & 51 & - \\
\hline
\end{tabular}

The data from HLA high-resolution genotyping for each patient included the information on both alleles of $\mathrm{A}^{*}, \mathrm{~B}^{*}, \mathrm{C}^{*}, \mathrm{DRB} 1^{*}, \mathrm{DQB} 1^{*}$ genes in the HLA histocompatibility complex (Group I-III HLA genotypes are presented in Supplemental Table 1). We performed this analysis for every gene and for each allele of a gene that had significant differences. The distribution of allele frequencies over 5 loci from three groups is presented in Figure 1.

For three groups, we used a method of distances upon pairwise comparison [21] using the fixation index F $_{\text {ST }}$ which is a special case of the Wright F-statistics based on the correlation of randomly chosen alleles within a population with the whole population which is equivalent to the ratio of genetic diversity due to the differences in allele frequency in populations [22]. Results are presented in Table 2. Zero and negative values of $F_{\text {ST }}$ mean that there was no genetic stratification between populations Group I and III are similar, group II is equidistant from both of them.

After that, we performed the population Assignment Test (Figure 2). For each sample population, we created a probability graph of the genotype within the sample from the population compared to the other populations. The results obtained are similar to those obtained from a pairwise comparison. 
5

A
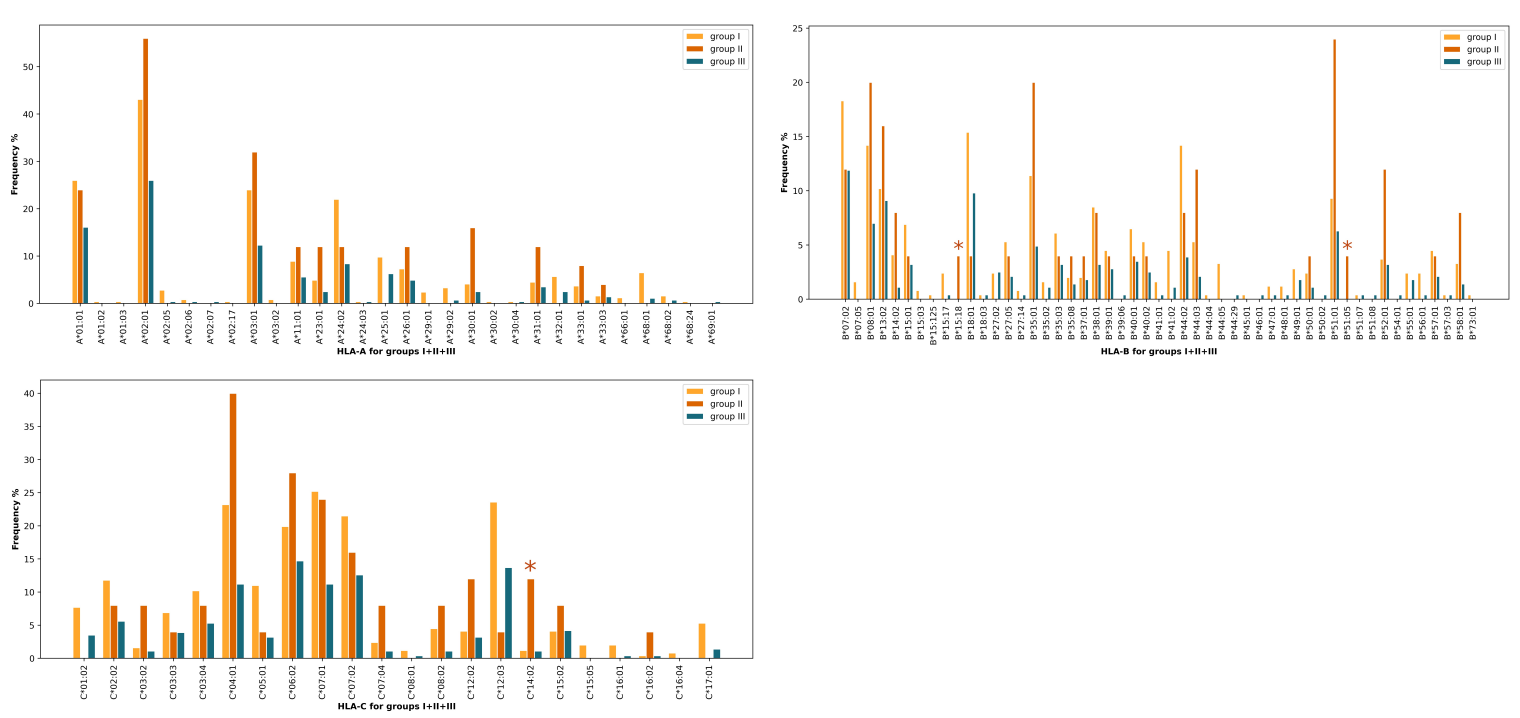

B
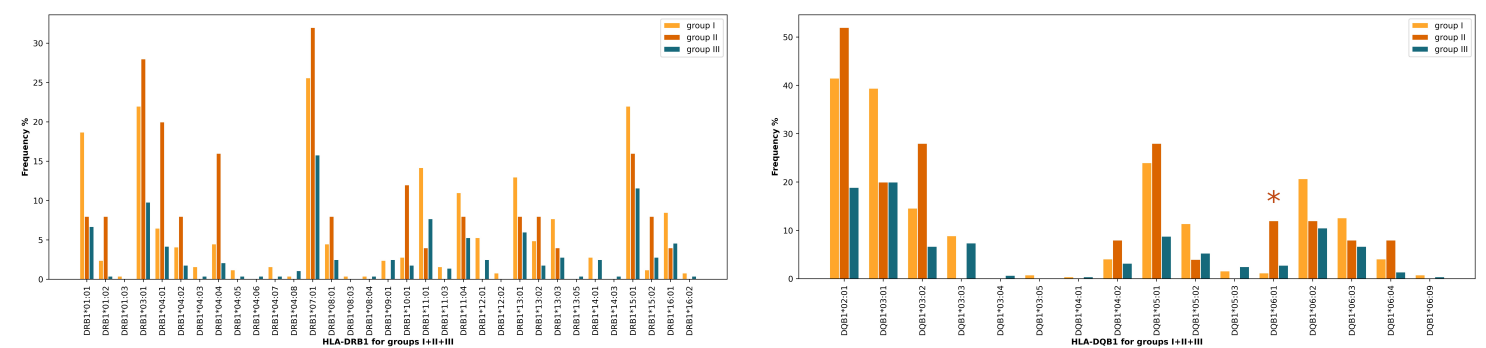

Figure 1. The histogram of the frequencies of alleles of class I (A) and class II (B) HLA loci. The horizontal axis, the value of the 1 st level allele. The vertical axis, its frequency in a sample population. Group I is denoted by yellow bars, group II is denoted by orange bars, group III is denoted by green bars. Starts denote the alleles that showed statistically significant associations.

Table 2. The results obtained by the distance method upon pairwise comparisons of groups I-III.

\begin{tabular}{|c|c|c|c|}
\hline Group & I & II & III \\
\hline I & 0 & & \\
\hline II & 0.00335 & 0 & \\
\hline III & -0.00045 & 0.00324 & 0 \\
\hline
\end{tabular}




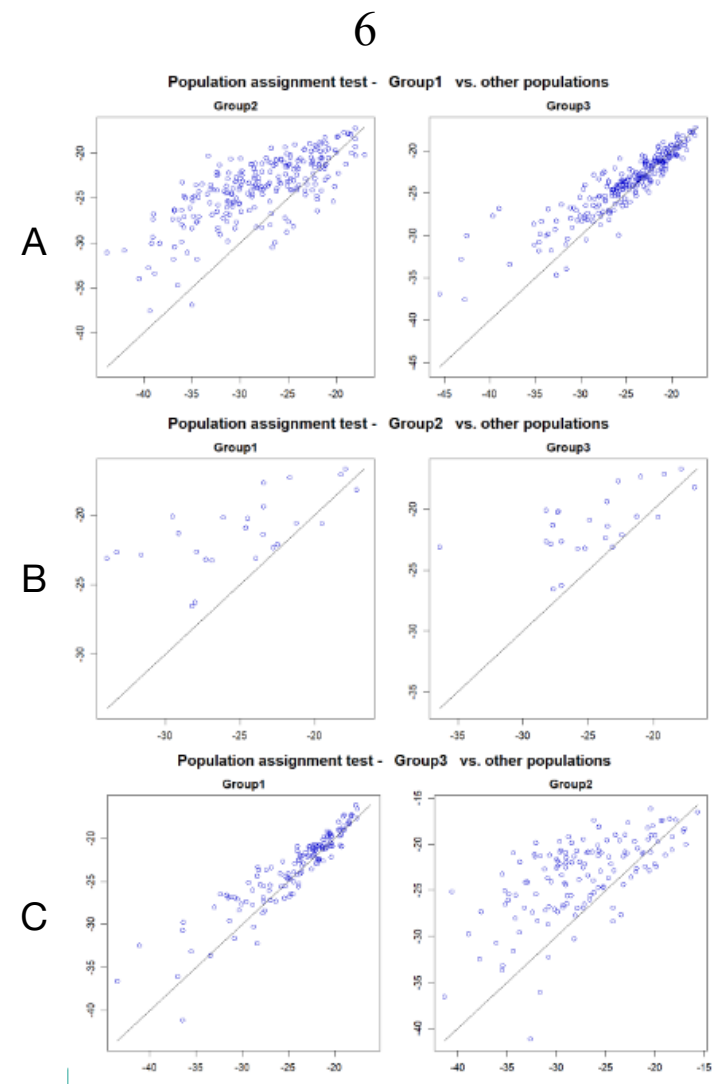

Figure 2. Results from the population Assignment Test. For each group (I - A, II - B, III - C), we created the genotype probability plot within the sample from the population compared to all other populations.

Alternatively, we used Pearson's goodness-of-fit test that enabled a separate analysis of each gene.

We analysed the 2-level alleles for each gene. The null hypothesis stated that HLA did not affect the divergence in the groups. We chose a p-value of 0.05 as a threshold value. We compiled a contingency matrix for each gene using one of four methods (Table 3). Although considering both alleles from each patient as independent ones (V2) is incorrect from the point of view of statistical analysis, we decided to perform this analysis in order to compare the results.

Table 3. Three ways to collect patient's data to compile a contingency matrix for each gene.

\begin{tabular}{|c|c|c|}
\hline Selection principle & The example of data & Degrees of freedom \\
\hline $\begin{array}{l}\text { One of the alleles of a patient } \\
\text { that was randomly selected } \\
\text { (V1) }\end{array}$ & $\begin{array}{c}26: 01 \text { ', '25:01', '30:01', '31:01', } \\
\text { '68:02', '02:17', '01:01', '23:01', } \\
\text { '33:01', '02:05', '02:01', '33:03', } \\
\text { '24:03', '29:02', '32:01', '03:02', } \\
\text { '29:01', '11:01', '66:01', '68:01', } \\
\text { '03:01', '24:02 }\end{array}$ & 22 \\
\hline $\begin{array}{l}\text { Both alleles analysed } \\
\text { independently (V2) }\end{array}$ & $\begin{array}{l}\text { 26:01', '30:02', '69:01', '25:01', } \\
\text { '30:01', '31:01', '68:02', '02:17', } \\
\text { '01:01', '23:01', '33:01', '02:05', } \\
\text { '01:03', '02:01', '33:03', '24:03', } \\
\text { '29:02', '32:01', '30:04', '03:02', } \\
\text { '29:01', '02:07', '11:01', '66:01', } \\
\text { '68:01', '68:24', '03:01', '02:06', }\end{array}$ & 50 \\
\hline
\end{tabular}


medRxiv preprint doi: https://doi.org/10.1101/2020.12.22.20248695; this version posted December 24, 2020. The copyright holder for this preprint (which was not certified by peer review) is the author/funder, who has granted medRxiv a license to display the preprint in It is made available under a CC-BY-NC 4.0 International license.

7

\begin{tabular}{|c|c|c|}
\hline & '24:02', '01:02' & \\
\hline $\begin{array}{c}\text { The joint analysis of an allele } \\
\text { pair (V3). }\end{array}$ & $\begin{array}{c}\text { 24:02_68:24', '25:01_68:02', } \\
\text { '03:01_30:04', '24:02_32:01', } \\
\text { '01:01_02:01', '01:01_25:01', } \\
\text { '01:02_29:02', '02:01_30:01', } \\
\text { '33:01_68:01', '25:01_33:01', } \\
\text { '03:02_68:01', '01:01_29:02', } \\
\ldots . \\
\text { '02:05_11:01', '01:01_68:01', } \\
\text { '23:01_23:01', '03:01_29:02', } \\
\text { '02:01_24:02', '03:01_33:03', } \\
\text { '24:02_29:02', '02:01_68:01', } \\
\text { '33:01_68:02', '03:01_23:01', } \\
\text { '24:02_24:02', '25:01_32:01', } \\
\text { '11:01_30:01', '01:01_03:01', } \\
\text { '02:01_30:04', '23:01_30:01 }\end{array}$ & 106 \\
\hline $\begin{array}{l}\text { Both alleles analyzed separately } \\
\text { based on the number of carriers } \\
\text { (V4) }\end{array}$ & $\begin{array}{c}\text { 26:01', '30:02', '69:01', '25:01', } \\
\text { '30:01', '31:01', '68:02', '02:17', } \\
\text { '01:01', '23:01', '33:01', '02:05', } \\
\text { '01:03', '02:01', '33:03', '24:03', } \\
\text { '29:02', '32:01', '30:04', '03:02', } \\
\text { '29:01', '02:07', '11:01', '66:01', } \\
\text { '68:01', '68:24', '03:01', '02:06', } \\
\text { '24:02', '01:02' }\end{array}$ & 50 \\
\hline
\end{tabular}

Analysis of the combined groups: I+II vs III (i.e. healthy or recovered donors vs patients who died from COVID-19), II+III vs I (i.e. all who suffered from COVID-19 vs healthy donors) didn't reveal any significant differences. Separate analysis of three groups revealed statistically significant effects of HLA-C* allele combinations (Table 4). As a multiple comparison correction, we used the Bonferroni method [23] with the significance level of 0.05 Locus $C^{*}$ significantly affects the group stratification. To determine significant alleles for each gene based on the way of compiling a contingency matrix, we created a special script. The results obtained for $\mathrm{V} 3$ are presented in Table 5. For alleles we considered only once, we chose the V4 method, as the results from the V1 method should be considered in the iterative dynamics due to the random choice of an allele. The results obtained from V4 are presented in Table 6.

Table 4. Comparison of groups I, II, and III of samples based on Pearson's goodness-of-fit test.

\begin{tabular}{|c|c|c|c|c|c|}
\hline \multirow{2}{*}{ Gene } & $\begin{array}{c}\text { Selection } \\
\text { principle }\end{array}$ & chi-square & P-value & $\begin{array}{c}\text { P-value corrected } \\
\text { by the } \\
\text { Bonferroni } \\
\text { method }\end{array}$ & $\begin{array}{c}\text { Degrees of } \\
\text { freedom }\end{array}$ \\
\hline \multirow{2}{*}{$\mathbf{A}^{*}$} & $\mathrm{~V} 1$ & 47.086 & 0.5102 & 1 & 48 \\
\cline { 2 - 6 } & $\mathrm{V} 2$ & 54.453 & 0.6079 & 1 & 58 \\
\hline
\end{tabular}


medRxiv preprint doi: https://doi.org/10.1101/2020.12.22.20248695; this version posted December 24, 2020. The copyright holder for this preprint (which was not certified by peer review) is the author/funder, who has granted medRxiv a license to display the preprint in perpetuity.

It is made available under a CC-BY-NC 4.0 International license .

\begin{tabular}{|c|c|c|c|c|c|}
\hline \multicolumn{6}{|c|}{8} \\
\hline & V3 & 209.643 & 0.4939 & 1 & 210 \\
\hline & V4 & 52.403 & 0.6825 & 1 & 58 \\
\hline \multirow{4}{*}{$\mathrm{B}^{*}$} & V1 & 76.211 & 0.765 & 1 & 86 \\
\hline & V2 & 103.91 & 0.374 & 1 & 100 \\
\hline & V3 & 500.36 & 0.272 & 1 & 482 \\
\hline & V4 & 103.375 & 0.3885 & 1 & 100 \\
\hline \multirow{4}{*}{$C^{*}$} & V1 & 74.573 & 0.0015 & 0.007 & 42 \\
\hline & V2 & 59.452 & 0.0391 & 0.1955 & 42 \\
\hline & V3 & 289.376 & 0.0036 & 0.018 & 228 \\
\hline & V4 & 58.905 & 0.0433 & 0.2165 & 42 \\
\hline \multirow{4}{*}{ DRB1* } & V1 & 45.435 & 0.8849 & 0.4424 & 58 \\
\hline & V2 & 60.157 & 0.6131 & 1 & 64 \\
\hline & V3 & 348.283 & 0.133 & 0.665 & 320 \\
\hline & V4 & 62.196 & 0.5405 & 1 & 64 \\
\hline \multirow{4}{*}{ DQB1* } & V1 & 46.97 & 0.0138 & 0.069 & 28 \\
\hline & V2 & 40.798 & 0.0903 & 0.4515 & 30 \\
\hline & V3 & 161.988 & 0.0226 & 0.113 & 128 \\
\hline & V4 & 41.247 & 0.0828 & 0.414 & 30 \\
\hline
\end{tabular}

Table 5. The list of statistically significant combinations of HLA gene alleles that define the differences between groups I, II, and III following the V3 method.

\begin{tabular}{|c|c|c|}
\hline Locus & $\begin{array}{c}\text { The significant allele } \\
\text { combination }\end{array}$ & $\begin{array}{l}\text { P-value corrected by the } \\
\text { Bonferroni method }\end{array}$ \\
\hline$A^{*}$ & $\begin{array}{l}30: 01 \_33: 03 \\
11: 01 \_23: 01\end{array}$ & $\begin{array}{l}0.0409 \\
0.0409\end{array}$ \\
\hline $\mathrm{B}^{*}$ & absent & 1 \\
\hline$C^{*}$ & $\begin{array}{l}04: 01 \_14: 02 \\
07: 04 \_14: 02 \\
07: 02 \_16: 02 \\
04: 01 \_08: 02 \\
07: 02 \_07: 04 \\
03: 03 \_14: 02\end{array}$ & $\begin{array}{l}0.0444 \\
0.0444 \\
0.0444 \\
0.0444 \\
0.0444 \\
0.0444 \\
\end{array}$ \\
\hline DRB1* & $\begin{array}{l}04: 01 \_11: 04 \\
04: 04 \_07: 01\end{array}$ & $\begin{array}{l}0.0075 \\
0.0075\end{array}$ \\
\hline DQB1* & $\begin{array}{l}03: 02 \_03: 02 \\
02: 01 \_06: 01\end{array}$ & $\begin{array}{l}0.0251 \\
0.0251\end{array}$ \\
\hline
\end{tabular}

Table 6. The list of statistically significant combinations of HLA gene alleles that define the differences between groups I, II, and III following the V4 method. 
medRxiv preprint doi: https://doi.org/10.1101/2020.12.22.20248695; this version posted December 24,2020 . The copyright holder for this preprint (which was not certified by peer review) is the author/funder, who has granted medRxiv a license to display the preprint in

9

\begin{tabular}{|c|c|c}
\hline A* & absent & 1 \\
\hline \multirow{2}{*}{ B* } & $\begin{array}{c}51: 05 \\
15: 18\end{array}$ & 0.0233 \\
\hline C* $^{*}$ & $\begin{array}{c}14: 02 \text { insignificantly exceeds } \\
\text { the threshold }\end{array}$ & 0.0233 \\
\hline DRB1* & absent & 1 \\
\hline DQB1* & $\begin{array}{c}\text { 06:01 insignificantly exceeds } \\
\text { the threshold }\end{array}$ & 0.0544 \\
\hline
\end{tabular}

To determine the significant alleles, we analysed the other group combinations, according to the V4 method. In particular, the group of deceased patients was divided into subgroups, according to their age (age not exceeding 65 or exceeding 65 at the time of death) and comorbidities. The group designations and sizes are presented in Table 7. The results obtained from the other combinations are presented in

Table 8 . We should note that we had to exclude some patients from the sample population (Table 1) due to the lack of full clinical data. The distribution of allele frequencies of the locus $C^{*}$ in the subgroups IIIA-IIID is presented in Figure 3.

Table 7. The designations and number of the groups subjected to analysis.

\begin{tabular}{|c|c|c|}
\hline Group name & Designation & Number \\
\hline $\begin{array}{c}\text { Bone marrow donors who didn't } \\
\text { suffer from COVID-19 }\end{array}$ & I & 245 \\
\hline $\begin{array}{c}\text { Bone marrow donors who had } \\
\text { COVID-19 }\end{array}$ & II & 25 \\
\hline $\begin{array}{c}\text { Patients who died from COVID- } \\
19\end{array}$ & III & 147 \\
\hline $\begin{array}{c}\text { Patients who died from COVID- } \\
19 \text { under age of 65. }\end{array}$ & IIIA & 30 \\
\hline $\begin{array}{c}\text { Patients who died from COVID- } \\
19 \text { above age of 65 }\end{array}$ & IIIB & 67 \\
\hline $\begin{array}{c}\text { Patients who died from COVID- } \\
19 \text { with comorbidities }\end{array}$ & IIIC & 83 \\
\hline $\begin{array}{c}\text { Patients who died from COVID- } \\
19 \text { without comorbidities }\end{array}$ & IIID & 14 \\
\hline
\end{tabular}

Table 8. Comparison of the group combinations analyzed by V4 method.

\begin{tabular}{|c|c|c|c|}
\hline Group combination & Locus & Significant allele & $\begin{array}{c}\text { P-value corrected by } \\
\text { the Bonferroni } \\
\text { method }\end{array}$ \\
\hline (I+II)+III & - & - & \\
\hline I+(II+III) & - & - & \\
\hline I+II+IIIA+IIIB & $\mathrm{C}^{*}$ & $14: 02$ & 0.03439 \\
\hline
\end{tabular}


medRxiv preprint doi: https://doi.org/10.1101/2020.12.22.20248695; this version posted December 24, 2020. The copyright holder for this preprint (which was not certified by peer review) is the author/funder, who has granted medRxiv a license to display the preprint in

10

\begin{tabular}{|c|c|c|c|}
\hline II+IIIA+IIIB & - & - & \\
\hline IIIA+IIIB & - & - & 0.0593 \\
\hline II+II)+IIIA+IIIB & DQB1* & $\begin{array}{c}03: 04 \text { insignificantly } \\
\text { exceeds the threshold }\end{array}$ & \\
\hline I+II & - & - & \\
\hline II+III & - & - & 0.0047 \\
\hline IIIC+IIID & - & $14: 02$ & 0.0637 \\
\hline IIIA+IIIB+IIIC+IIID & $\mathrm{C}^{*}$ & $\begin{array}{c}14: 02 \text { insignificantly } \\
\text { exceeds the threshold }\end{array}$ & \\
\hline II+IIIC+IIID & $\mathrm{C}^{*}$ & - & \\
\hline I+II+IIIC+IIID & - & & \\
\hline
\end{tabular}

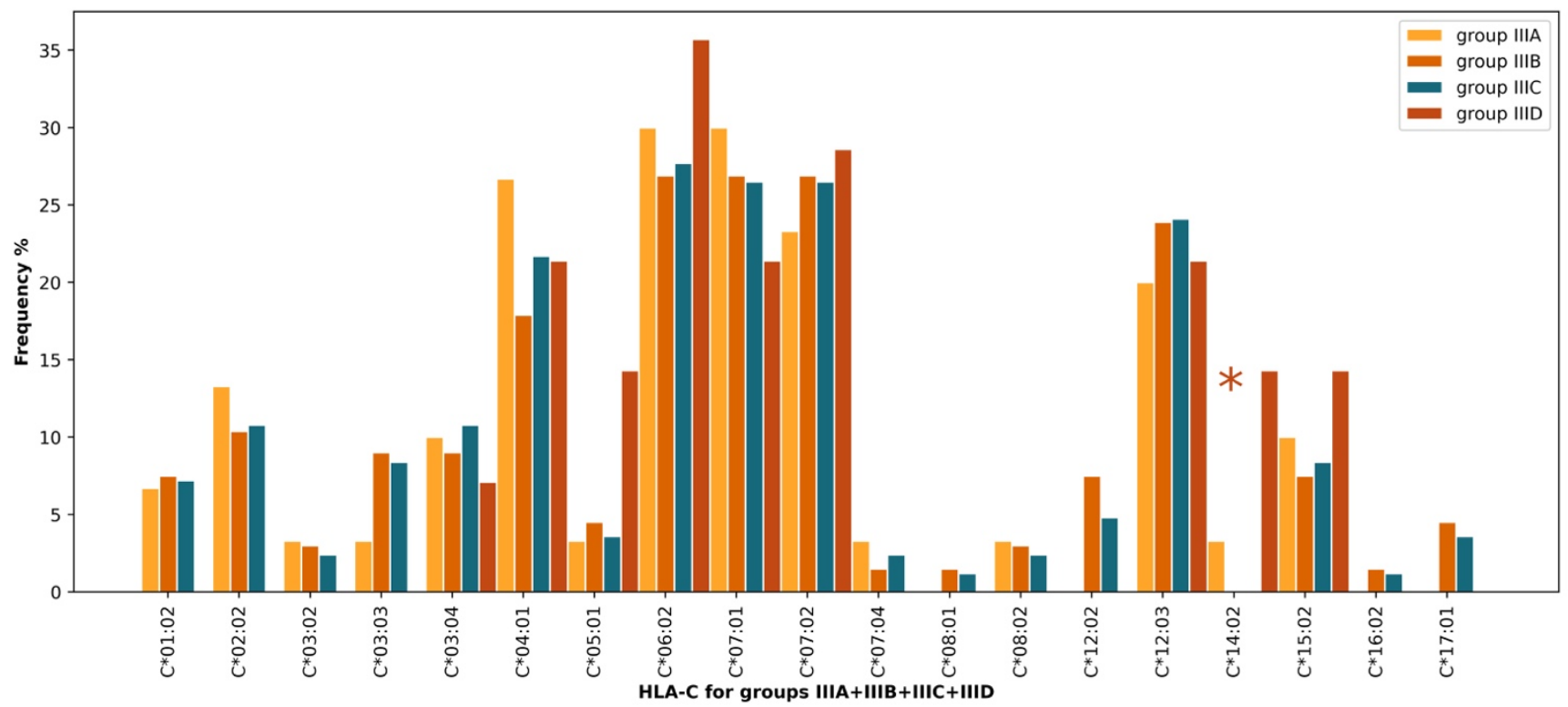

Figure 3. The distribution of allele frequencies of locus $C *$ in the patients who died from COVID-19. The subgroups are indicated in the diagram.

\section{Discussion}

Thus, locus $\mathrm{C}^{*}$ statistically significantly affects the groups of patients who didn't suffer from COVID-19, recovered and died (Table 4); estimating the significance of allele combinations reveal statistically significant associations with COVID-19 severity (Table 5). Locus B 51:05 and 15:18 alleles show statistically significant association with the COVID-19 severity (Table 6), while the p-value of $C^{*} 14: 02$ and DQB1*06:01 alleles are close to the threshold value. Upon stratification of the patients who died from COVID-19 according to their age, $\mathrm{C}^{*}$ 14:02 allele was significant (Table 8).

Importantly, the manipulations with group stratification based on various parameters allow determining a criterion that would make the stratification significant. This is related to a limited size of the experimental sample population. Therefore, we are planning to confirm the results obtained in this work using a larger sample that is 
medRxiv preprint doi: https://doi.org/10.1101/2020.12.22.20248695; this version posted December 24, 2020. The copyright holder for this preprint (which was not certified by peer review) is the author/funder, who has granted medRxiv a license to display the preprint in

being collected at the moment. We hope to obtain conclusive evidence regarding the C*14:02 and DQB1*06:01 alleles.

We performed a comparative analysis of the previously published results on the search for the association between HLA and COVID-19 severity (Table 9). Statistically significant and close to statistically significant $B^{*} 51, C^{*} 14: 02$, and DQB1*06:01 alleles we singled out in our work turned out to be identified in other works as well. Some divergences in the results may be accounted for distinct frequencies of HLA alleles within the particular ethnic groups.

Table 9. Comparison of the results on alleles for COVID-19 obtained by other investigators

\begin{tabular}{|c|c|c|c|c|c|c|}
\hline Paper & Comment & $A^{*}$ & $\mathbf{B}^{*}$ & $C^{*}$ & DRB1* & DQB1* \\
\hline Our data & & & $\begin{array}{l}51: 05 \\
15: 18\end{array}$ & $14: 02^{1}$ & & $06: 01^{1}$ \\
\hline [24] & $\begin{array}{l}\text { severe patients } \\
\text { compared to the mild }\end{array}$ & 11:01 & 51:01 & $14: 02$ & & \\
\hline$[25]$ & $\begin{array}{l}\text { individuals with this } \\
\text { allele may be } \\
\text { particularly vulnerable } \\
\text { to COVID-19 }\end{array}$ & & $46: 01$ & $12: 03$ & & \\
\hline$[26]$ & $\begin{array}{l}\text { analyzing infected } \\
\text { SARS patients and } \\
\text { high risk health care } \\
\text { workers groups, } \\
\text { severity of SARS was } \\
\text { shown to be } \\
\text { significantly associated } \\
\text { with: }\end{array}$ & & $\begin{array}{c}46: 0154: 01 \\
13: 01\end{array}$ & 01:02 & & \\
\hline [27] & $\begin{array}{c}\text { strong association } \\
\text { between SARS and } \\
\text { HLA allele }\end{array}$ & & $\begin{array}{l}07: 03 \text { and } 60 \\
\text { coinheritance }\end{array}$ & & 03:01 & 06:01 \\
\hline$[28]$ & $\begin{array}{c}\text { association between } \\
\text { HLA genes and } \\
\text { susceptibility/resistance } \\
\text { to SARS exists }\end{array}$ & 26 & & & $04,16,09$ & \\
\hline [29] & & & 07:03 & & 03:01 & \\
\hline
\end{tabular}

\section{Conclusions}

Locus $B * 51: 05$ and 15:18 alleles show statistically significant association with COVID-19 severity upon comparing the sample populations of patients in Russia who died from coronavirus infection with the group of bone marrow donors. They are more frequent in patients who recovered from COVID-19. The C*14:02 allele revealed a

\footnotetext{
${ }^{1}$ In our study, p-value of $C^{*} 14: 02$ and $\mathrm{DQB} 1 * 06: 01$ alleles is very close to the threshold value, however exceeds it.
} 
medRxiv preprint doi: https://doi.org/10.1101/2020.12.22.20248695; this version posted December 24, 2020. The copyright holder for this preprint (which was not certified by peer review) is the author/funder, who has granted medRxiv a license to display the preprint in

It is made available under a CC-BY-NC 4.0 International license.

12

statistically significant correlation with the increased probability of death from COVID19 of patients without comorbidities.

\section{Funding}

This research was funded by grant №075-15-2019-1789 from the Ministry of Science and Higher Education of the Russian Federation allocated to the Center for Precision Genome Editing and Genetic Technologies for Biomedicine.

\section{Acknowledgments}

\section{Conflicts of Interest}

The authors declare no conflict of interest.

\section{References}

1. Meyerowitz-Katz G, Merone L. A systematic review and meta-analysis of published research data on COVID-19 infection fatality rates. Int $J$ Infect Dis. 2020 Sep 29; 101:138-148.

2. WHO. Coronavirus disease (COVID-19) Weekly Epidemiological Update and Weekly Operational Update: Weekly Epidemiological Update 13 November $2020 \mathrm{https}: / / \mathrm{www}$. who.int/emergencies/diseases/novel-coronavirus2019/situation-reports (2020).

3. Mao, Ren, et al. "Manifestations and prognosis of gastrointestinal and liver involvement in patients with COVID-19: a systematic review and metaanalysis." The lancet Gastroenterology \& hepatology (2020).

4. Spinato, Giacomo, et al. "Alterations in smell or taste in mildly symptomatic outpatients with SARS-CoV-2 infection." Jama (2020).

5. Vetter, P. et al. Clinical features of COVID-19. Br. Med. J. 369, m1470 (2020).

6. Zhou, F. et al. Clinical course and risk factors for mortality of adult inpatients with COVID-19 in Wuhan, China: a retrospective cohort study. Lancet 395, 1054-1062 (2020).

7. Ellinghaus, D. et al. Genomewide association study of severe COVID-19 with respiratory failure. N. Engl. J.Med. https://doi.org/10.1056/NEJMoa2020283 (2020).

8. Cascella M, Rajnik M, Cuomo A, et al. Features, Evaluation, and Treatment of Coronavirus. [Updated 2020 Oct 4]. In: StatPearls [Internet]. Treasure Island (FL): StatPearls Publishing; 2020 Jan-. Available from: https://www.ncbi.nlm.nih.gov/books/NBK554776/ 
9. Nguyen, A., David, J. K., Maden, S. K., Wood, M. A., Weeder, B. R., Nellore, A., \& Thompson, R. F. (2020). Human leukocyte antigen susceptibility map for SARS-CoV-2. Journal of virology.

10.Iturrieta-Zuazo, I., Rita, C. G., García-Soidán, A., de Malet Pintos-Fonseca, A., Alonso-Alarcón, N., Pariente-Rodríguez, R., Tejeda-Velarde, A., Serrano-Villar, S., Castañer-Alabau, J. L., \& Nieto-Gañán, I. (2020). Possible role of HLA class-I genotype in SARS-CoV-2 infection and progression: A pilot study in a cohort of Covid-19 Spanish patients. Clinical immunology (Orlando, Fla.), 219, 108572.

11.Warren, R. L., \& Birol, I. (2020). Retrospective in silico HLA predictions from COVID-19 patients reveal alleles associated with disease prognosis. medRxiv : the preprint server for health sciences, 2020.10.27.20220863.

12.Pisanti, S., Deelen, J., Gallina, A. M., Caputo, M., Citro, M., Abate, M., Sacchi, N., Vecchione, C., \& Martinelli, R. (2020). Correlation of the two most frequent HLA haplotypes in the Italian population to the differential regional incidence of Covid-19. Journal of translational medicine, 18(1), 352.

13.Warren, R. L., \& Birol, I. (2020). HLA predictions from the bronchoalveolar lavage fluid samples of five patients at the early stage of the Wuhan seafood market COVID-19 outbreak. ArXiv, arXiv:2004.07108v3.

14.Wang, W., Zhang, W., Zhang, J., He, J., \& Zhu, F. (2020). Distribution of HLA allele frequencies in 82 Chinese individuals with coronavirus disease-2019 (COVID-19). HLA, 96(2), 194-196.

15.Barquera, R., Collen, E., Di, D., Buhler, S., Teixeira, J., Llamas, B., Nunes, J. M., $\&$ Sanchez-Mazas, A. (2020). Binding affinities of 438 HLA proteins to complete proteomes of seven pandemic viruses and distributions of strongest and weakest HLA peptide binders in populations worldwide. HLA, 96(3), 277-298.

16.Goverdhan, S. V., Howell, M. W., Mullins, R. F., Osmond, C., Hodgkins, P. R., Self, J., ... \& Lotery, A. J. (2005). Association of HLA class I and class II polymorphisms with age-related macular degeneration. Investigative ophthalmology \& visual science, 46(5), 1726-1734.

17.Teixeira, S. L. M., De Sá, N. B. R., Campos, D. P., Coelho, A. B., Guimaraes, M. L., Leite, T. C. N. F., ... \& Morgado, M. G. (2014). Association of the HLA-B* 52 allele with non-progression to AIDS in Brazilian HIV-1-infected individuals. Genes \& Immunity, 15(4), 256-262.

18.Karnes, J. H., Shaffer, C. M., Bastarache, L., Gaudieri, S., Glazer, A. M., Steiner, H. E., ... \& Roden, D. M. (2017). Comparison of HLA allelic imputation programs. PLoS One, 12(2), e0172444.

19.Ding, S. J., Zhang, Y., Zhang, X. M., Jiang, X. L., Pang, B., Song, Y. H., ... \& Yu, X. J. (2016). Correlation Between HLA-A, B and DRB1 Alleles and Severe 
14

Fever with Thrombocytopenia Syndrome. PLoS neglected tropical diseases, 10(10), e0005076.

20.Excoffier, L., \& Lischer, H. E. (2010). Arlequin suite ver 3.5: a new series of programs to perform population genetics analyses under Linux and Windows. Molecular ecology resources, 10(3), 564-567.

21.Beerli, P. (2005). Pairwise distance methods. Computational Evolucionary Biology, No BSC5936-Fall, 1-7.

22.Holsinger, K. E., \& Weir, B. S. (2009). Genetics in geographically structured populations: defining, estimating and interpreting F ST. Nature Reviews Genetics, 10(9), 639-650.

23.Bland, J. M., \& Altman, D. G. (1995). Multiple significance tests: the Bonferroni method. Bmj, 310(6973), 170.

24.Wang, F., Huang, S., Gao, H., Zhou, Y., Lai, C., Li, Z., ... \& Tang, Q. (2020). Initial Whole Genome Sequencing and Analysis of the Host Genetic Contribution to COVID-19 Severity and Susceptibility. medRxiv.

25.3Nguyen, A., David, J. K., Maden, S. K., Wood, M. A., Weeder, B. R., Nellore, A., \& Thompson, R. F. (2020). Human leukocyte antigen susceptibility map for SARS-CoV-2. Journal of virology.

26.Lin, M., Tseng, H. K., Trejaut, J. A., Lee, H. L., Loo, J. H., Chu, C. C., ... \& Lin, R. Y. (2003). Association of HLA class I with severe acute respiratory syndrome coronavirus infection. BMC Medical Genetics, 4(1), 9.

27.Ng, M. H., Lau, K. M., Li, L., Cheng, S. H., Chan, W. Y., Hui, P. K., ... \& Sung, J. J. (2004). Association of human-leukocyte-antigen class I (B* 0703) and class II (DRB1* 0301) genotypes with susceptibility and resistance to the development of severe acute respiratory syndrome. Journal of Infectious Diseases, 190(3), 515-518.

28.Liu, D., Qiu, Y., Zha, Y., Li, W., Li, D., \& Wu, T. (2018). Association of HLA classIand classIIgenes with severe acute respiratory syndrome in the northern Chinese population.

29. Sanchez-Mazas, A. (2020). HLA studies in the context of coronavirus outbreaks. Swiss Medical Weekly, 150(1516). 
A
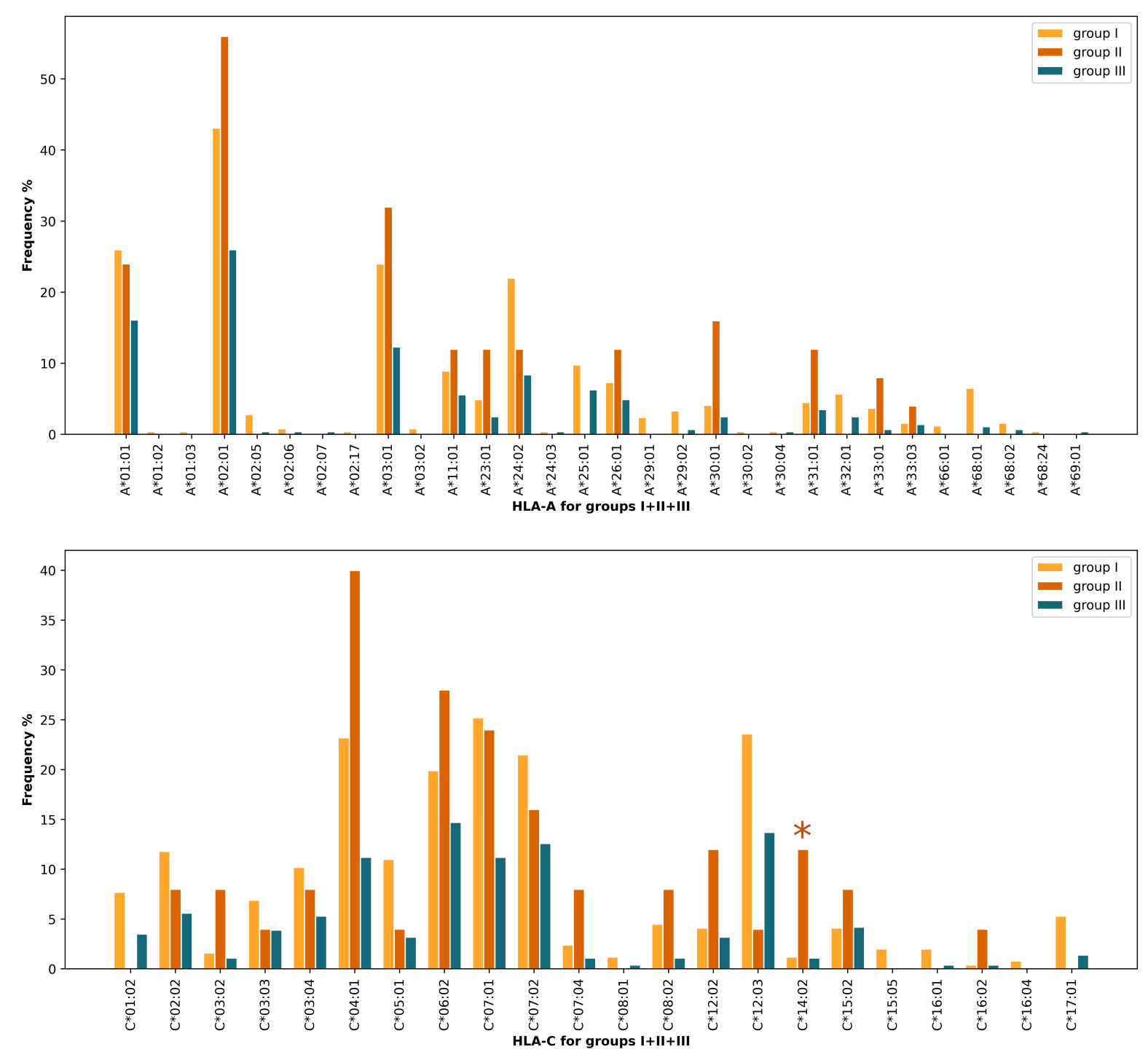

B

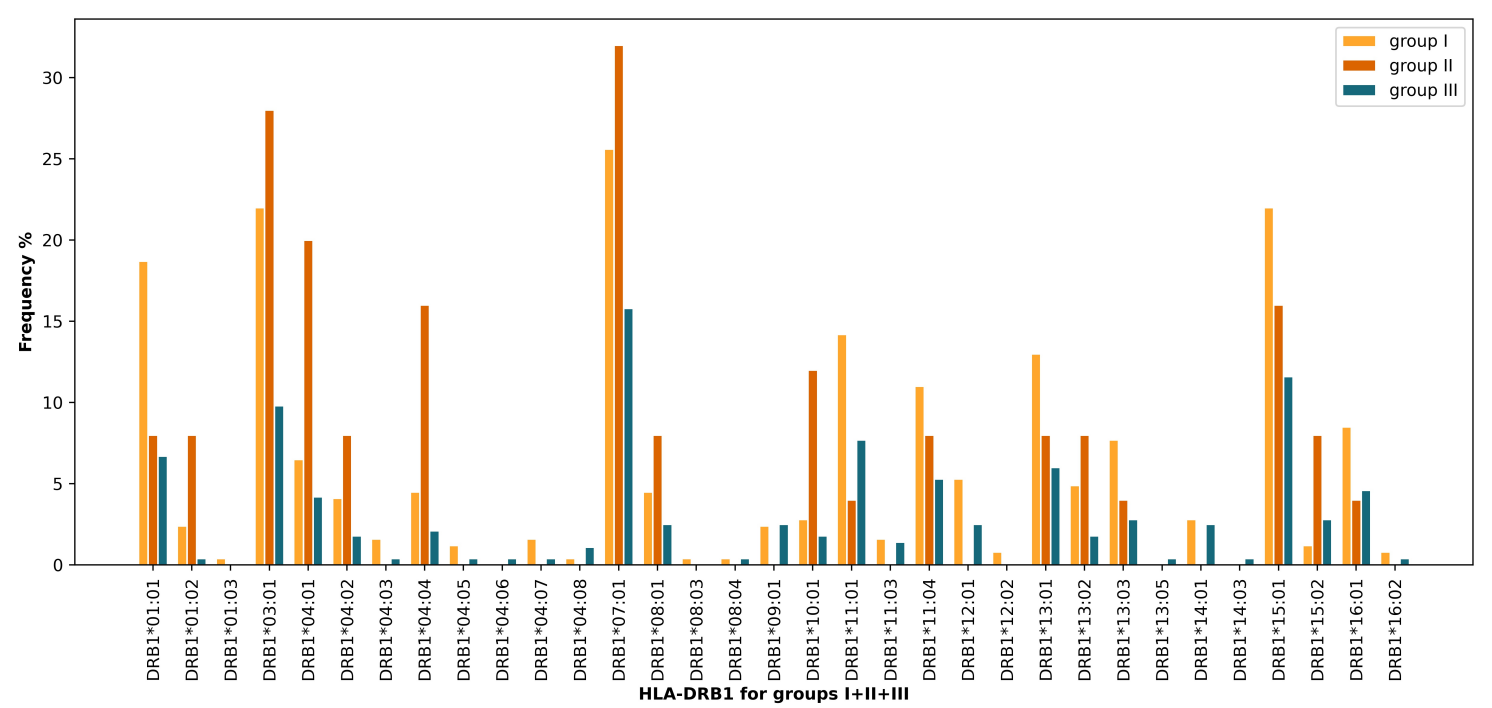

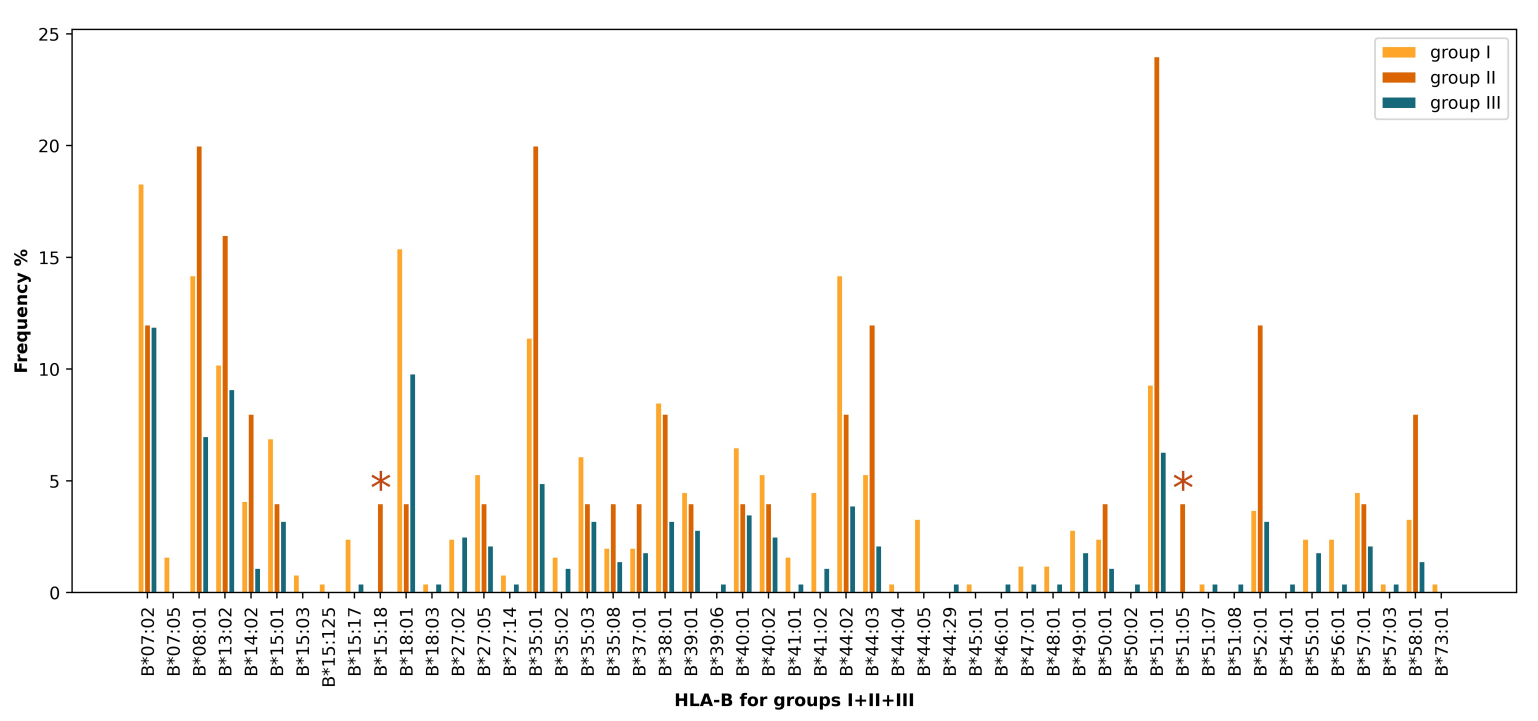

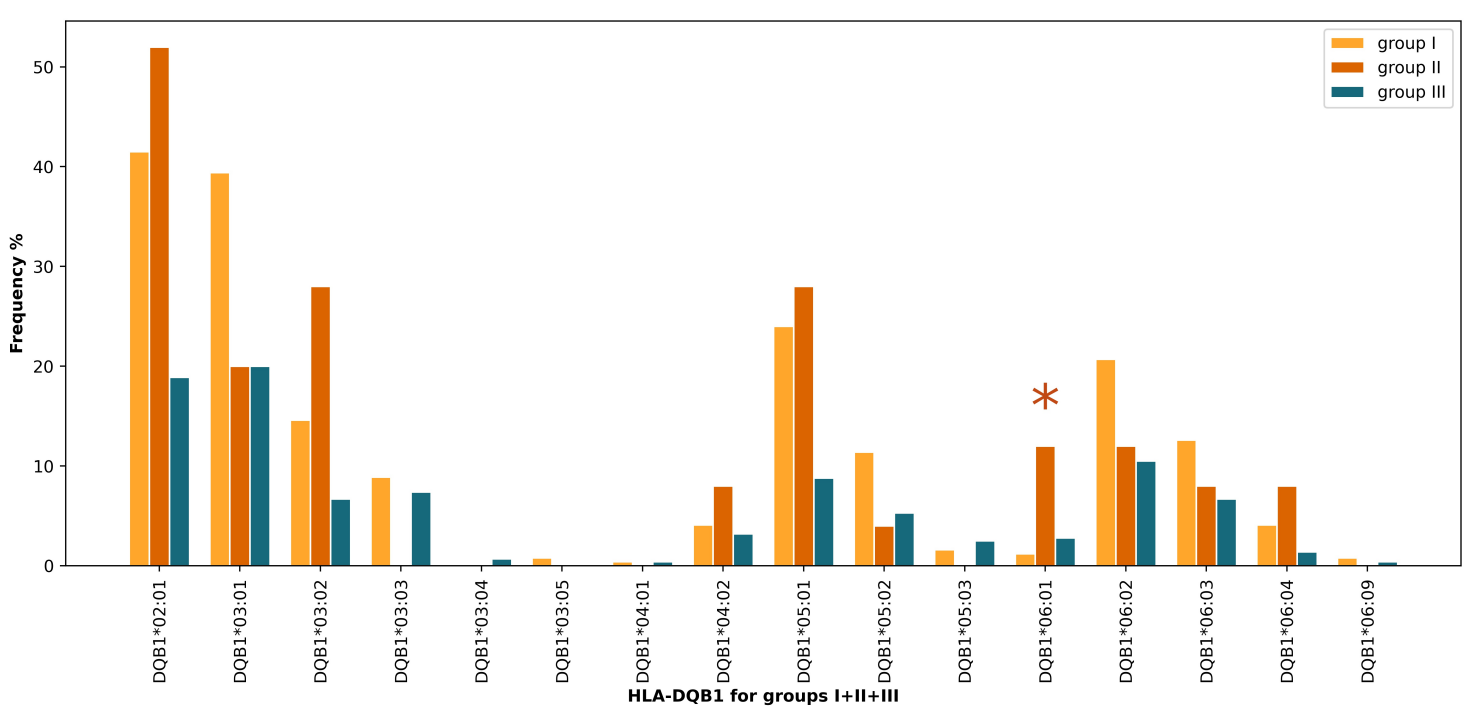


Population assignment test - Group1 vs. other populations
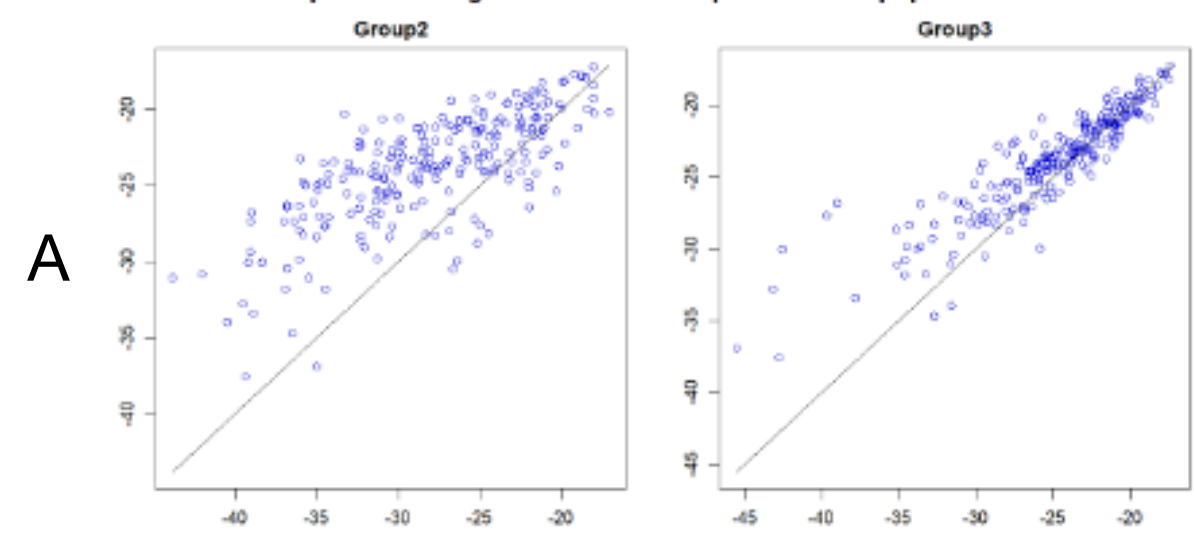

Population assignment test - Group2 vs. other populations
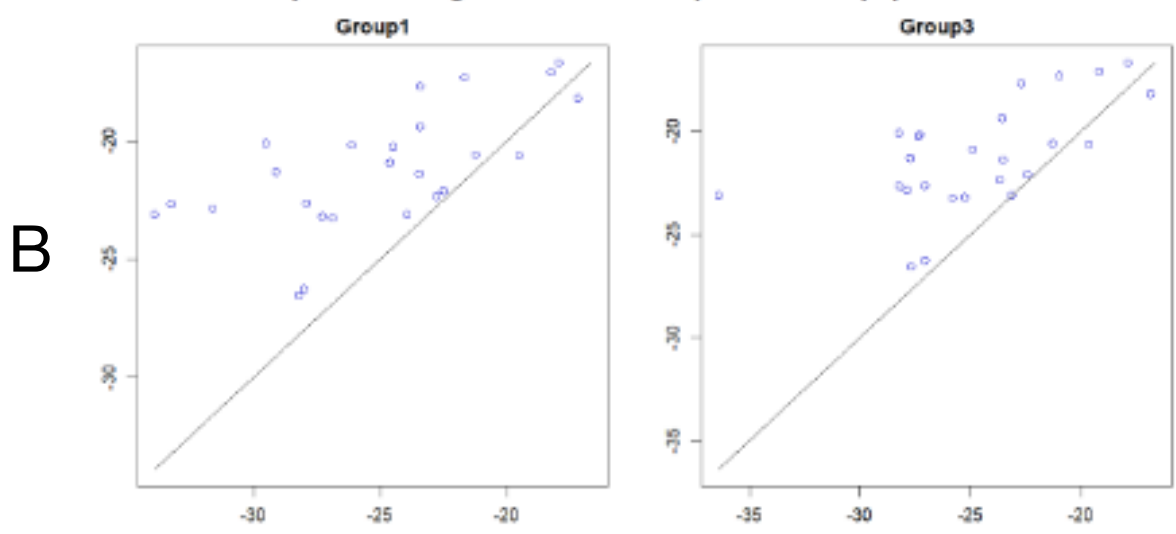

Population assignment test - Group3 vs. other populations
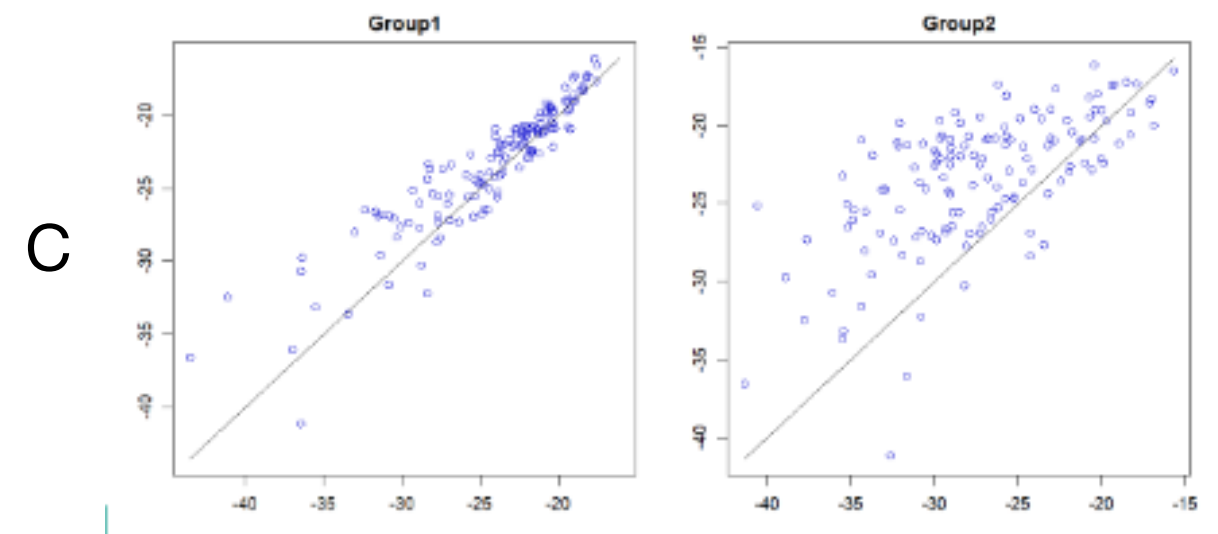
